crystallised or fragmentary, which will, unless the units be all of the same composition, crystallography, form, and orientation, store strain energy if subjected to any form of loading. Ease of weathering of any given rock unit in a uniform environment is therefore not only dependent upon the lithology involved but also upon its previous loading history as reflected in the intensity of jointing and residual strain energy level which the rock unit may possess.

It is of interest to note that the product of weathering by release of intergranular strain energy would consist of a loose aggregate of the various grains or crystals which comprised the initial rock mass. Once so released the individual mineralogy of the grains would determine their degree of survival. Such a mechanism of formation is easily applied to many of the weathering products of such widely contrasted rock types as granite and sandstone. The gritstone Edges of Derbyshire and Staffordshire show the production of a loose discretely granular sand the origin of which may be cxplained by a combination of conventional processes of weathering aiding the release of intergranular stresses, while the presence of the decply rotted granite, or growan, over much of Dartmoor may also owe its origin, at least in part, to this mechanism. The occurrence of the growan on Dartmoor separating the upstanding masses of the relatively unaltered tors (Linton 1955) thus leads to the further consideration that perhaps the tors represent zones of low initial strain energy level. This, in turn, would then be reflected in the development of only a widely spaced joint system in these zones when the granite was uplifted to its present position, with little residual strain energy remaining after jointing to facilitate intergranular breakdown. In contrast. the areas of growan would then correspond to zones of high initial strain energy level with the later development of a tight joint system in which a high residual strain energy level remained and aided cven fur ther the breakdown of the internal rock structure.

\title{
REFERENCES
}

IMI:RY,C. L. 1964. Strain Energy in Rocks. p.235. 260 in State of Stress in the Larth is Crust. (Fd. W. R. Judd). Elsevier, New York.

LINTON, D. L. 1955. The problem of tors. Geog. J., 121, 470.486.

PRICE, N. J. 1959. Mechanics of jointing in rocks. Geol. Mag., 96, 149167 1964. A study of time-strain behaviour of coal measure rocks. Int. J. Rock Mech. Min. Sci., 1, $277 \ldots 303$.

\author{
DEPARTMENT OF GEOLOGY, \\ UNIVERSITY OF EXETER, \\ EXETER. \\ 14 th March, 1969.
}

E. M. DURRANCl:

\section{CARBONIFEROUS CONODONTS IN THE SOUTH-WESTERN PENNINES}

SIR, - An investigation, by the author, of conodont faunas in the Lower Carboniferous rocks of the south-western Pennines is at present in progress. This work demonstrates the occurrence of conodont faunas which appear to fill a gap in the succession of conodont assemblage zones proposed by Rhodes, Austin \& Druce (1969). These authors demonstrated that yields of conodonts were very low from the dolomitic limestones of the Upper Caninia $\left(\mathrm{C}_{2}\right)$ Zone of the Avon Gorge sections, near Bristol. They suggested that the low yields might be due either to destruction by secondary dolomitisation or to the existence of an unfavourable depositional environment. More recent investigations by Austin, Conil \& Rhodes (personal communication) suggest that there is also a non-sequence at the base of the Caninia Oolite in the South-Western Province.

The paucity of conodont faunas from the Upper Caninia $\left(C_{2}\right)$ Zone is probably due to unfavourable environment since the writer has found that complete secondary dolomitisation of a limestone band in the Namurian of north Staffordshire has had no appreciable effect on the micro-structure of a large and very varied conodont fauna. 
Faunas isolated from limestones from Brownend Quarry, Waterhouses, north Staffordshire (Grid Reference SK 090502) include the interesting conodont species Scaliognathus anchoralis Branson and Mehl together with Hindeodella segaformis Bischoff, Gnathodus antetexanus Rexroad and Scott, Mestognathus beckmanni Bischoff and Bactrognathus perplanus Mehl and Thomas. Scarce, broken conodonts are possibly referable to the genera Elictognathus Cooper and Pelekysgnathus Thomas.

About 50 metres of thinly bedded limestones are exposed in Brownend Quarry; each of these bands has been sampled and is being processed. The Scaliognathus anchoralis fauna has so far been traced through some 14.4 metres of limestone. The fauna is most abundant and varied in a thin limestone band immediately below the level at which it disappears. The majority of the limestones above that containing the last $S$. anchoralis yield few conodonts, but small faunas isolated from some of the bands are still being studied. The full distribution of $S$. anchoralis downwards is uncertain at present but limestones low in the succession have already yielded faunas of a significantly different aspect from the Scaliognathus anchoralis-Hindeodella segaformis assemblage.

The $S$. anchoralis $-H$. segaformis assemblage referred to above is markedly different from any of those described by Rhodes et al. (1969). Gnathodid elements of the fauna are not particularly abundant or varied and are mostly referable to the species Gnathodus antetexanus Rexroad and Scott. This species continues up into the beds succeeding the $S$. anchoralis $-H$. segaformis assemblage and some specimens show a transition towards G. texanus Roundy. I am indebted to Dr. R. L. Austin for the advice that the gnathodids from Brownend Quarry appear to represent forms younger than those present in the Laminosa Dolomite $\left(C_{1}\right)$ of the Avon Gorge but older than those forms occurring in the Caninia Oolite of Gower. Thus it would seem that the north Staffordshire Scaliognathus anchoralis conodont assemblage is of late $C_{1}$ age. Prentice (1951) regarded the strata of Brownend Quarry as belonging to the Lower Caninia $\left(C_{1}\right)$ Zone while Ludford $(1951)$ and Parkinson \& Ludford (1964) placed these rocks in the Upper Caninia $\left(\mathrm{C}_{2}\right)$ Zone. The non-sequence at the base of the Caninia Oolite in the South-West Province referred to above, lies within the Mestognathus beckmanni-Polygnathus bischoffi Assemblage Zone of Rhodes et al. (1969). The exact limits of the $S$. anchoralis-H. segaformis fauna from north Staffordshire with reference to the faunal assemblage zones of Rhodes et al. cannot be assessed until the details of the north Staffordshire succession are more fully known.

Although a wide-ranging form in a geographical sense, the vertical distribution of the species Scaliognathus anchoralis is somewhat problematical. It has been recorded for example, from Lower Carboniferous (Mississippian) rocks of the United States by Branson \& Mehl (1941), from north-west Spain by Boogaert (1967), from the FrancoBelgian region by Conil, Lys \& Mauvier (1964) and from Germany by Bischoff (1957) and Voges (1960). Matthews $(1961 ; 1966)$ has identified anchoralis faunas from southwest England. The record of $S$. anchoralis in Zone Tn3b in Belgium by Conil et al. (1964) has been modified by Conil, Pirlet \& Lys (1967), who showed that the species actually occurs from the lowermost part of Zone $\operatorname{Tn} 3 \mathrm{c}$ to the Viséan Zone V1a. In Germany anchoralis faunas are restricted to Zone CuII $\beta / \gamma$. The problem of correlating the zonal schemes used in the Franco-Belgian area, in Germany and in Britain still remains.

Rhodes et al. (1969) suggested that Zone Tn3b of the Ftanco-Belgian succession may be equated with the German CuII $\beta / \gamma$ Zone and possibly also with Zone Cull $\delta$ This correlation must be modified to read Zone $\mathrm{Tn} 3 \mathrm{c}$ and Zone V1a of the Belgian succession. If the equation of $\mathrm{Tn} 3 \mathrm{c}-\mathrm{Vla}$ and $\mathrm{CuII} \beta / \gamma-\delta$ is correct the occurrence of anchoralis faunas in Staffordshire suggests a correlation of the Staffordshire faunas with these continental zones. Rhodes et al. (op. cit. p. 64-65) were uncertain as to the reason for the absence of the $S$. anchoralis fauna from the Avon Gorge. The evidence presented in this text suggests a gap in the conodont sequence established by Rhodes et al. (1969).

\section{REFERENCES}

BISCHOFF, G. 1957. Die Conodonten-Stratigraphie des rheno-herzynischen Unterkarbons mit Berucksichtigung der Wocklumeria-Stufe und der Devon/KarbonGrenze. Abh. hess. Landesamt Bodenforsch., 19, 1-64, pl. 1-6. 
BOOGAERT, H. A. Van A. 1967. Devonian and Lower Carboniferous Conodonts of the Cantabrian Mountains (Spain) and their Stratigraphic Application. Leidse Geol. Med., 39, 129-192, pls. 1-3.

BRANSON, E. B. \& MEHL, M. G. 1941. New and Little Known Carboniferous Conodont Genera. J. Paleont., 15, 97-106, pl. 19.

CONIL, R., LYS, M. \& MAUVIER, A. 1964. Critères micropaléontologiques éssentiels des formations-types du Carbonifère (Dinantien) du Bassin Franco-Belge. C. R. Congr. Avanc. Etud. Stratigr. carb. (Paris 1963), 1, 325-332.

Belgique. Service géol. Belg. Prof. Pap., 13, 1-56.

LUDFORD, A. 1951. The Stratigraphy of the Carboniferous Rocks of the Weaver Hills District, north Staffordshire. Q. Jl geol. Soc., Lond., 106, $211-230$, pl. 16.

MATTHEWS, S. C. 1961. A Carboniferous conodont fauna from Callington, East Cornwall. R. geol. Soc. Corm., Proc. 4th Conf. Geol. and Geomorph. working in the south-west of England, 13-15.

1966. Lower Carboniferous Stratigraphy in the St. Mellion area. Proc. Ussher Soc., Redruth, 1, 227-229.

PARKINSON, D. \& LUDFORD, A. 1964. The Carboniferous Limestone of the Blorewith-Swinscoe District, north-east Staffordshire, with revisions to the stratigraphy of Neighbouring areas. Geol. J., 4, 167-176, pl. 8.

PRENTICE, J. E. 1951. The Carboniferous Limestone of the Manifold Valley Region, north Staffordshire. $Q$. Il geol. Soc., Lond., 106, 171-210, pl. 15.

RHODES, F. H. T., AUSTIN, R. L. \& DRUCE, E. C. 1969. British Avonian (Carboniferous) Conodont Faunas, and their value in local and intercontinental correlation. Bull. Br. Mus. nat. Hist. (Geol) Supplement 5, 1-313, p. 1-31.

VOGES, A. 1960. Die Bedeutung der Conodonten für die Stratigraphie des Unterkarbon I und II (Gattendorfia- und Pericyclus-Stufe) im Sauerland. Fortschr. Geol. Rheinld Westf., Krefeld., 3, 197-228.

\section{P. G. MORRIS}

DEPARTMENT OF GEOLOGY,

CHELSEA COLLEGE OF SCIENCE \& TECHNOLOGY,

MANRESA ROAD,

LONDON, S.W.3.

30th June, 1969.

\section{REVIEWS}

SYLVESTER-BRADLEY, P. C. \& FORD, T. D. (Eds.) 1968. The Geology of the East Midlands. $\mathrm{xx}+400$ p., 57 figs., 19 tables, 7 pls. Leicester University Press. Price f4 $4 s$.

This is a very welcome detailed survey of contemporary knowledge of the geology of a considerable area of England which does not in itself form a natural unit. On the contrary it includes parts of several more intact geological entities so that a proper understanding of East Midland geology, particularly of the Palaeozoic, requires a broader knowledge of that of other parts of Britain. This is in most cases adequately catered for in the introductions to the Palaeozoic chapters. The region is built of rocks with an almost continuous history from late Pre-Cambrian to Recent, the only major gaps being during middle Palaeozoic and Tertiary times.

The plan of the book is a chronological one. Each chapter has been written by one or more authors (17 authors in all), for the most part specialists in that part of the geological column they treat, and all with an intimate knowledge of the local geology. In this kind of compilation there is bound to be variation in the bias and approach of the 